\title{
Establishment of a strategy of circular economy increasing the well-being of society: comparison of two national policies
}

\author{
Boris Kalioujny, Janna Ermushko, and Anastasia Zhavoronok \\ Tomsk Polytechnic University, 634050 Lenin Avenue, 30, Tomsk, Russia
}

\begin{abstract}
The paper considers a new paradigm of sustainable development, establishing new ways of societal progress and success based on the concepts other than only economic growth and material wealth. Sustainable development suggests that the wellbeing of the society depends, among other, on clean and healthy environment, and on the mutual interaction of human beings realized in new models of economics and behaviour. This article describes a new model of economics based on the interaction of environmental protection and economic efficiency, the model of circular economy (CE). The paper compares two different macro-economical approaches integrating the $\mathrm{CE}$ model into national economy strategies. The existing $\mathrm{CE}$ instruments and mechanisms are explored demonstrating the results of such policy application at meso- and micro- levels.
\end{abstract}

\section{Introduction}

In 1971, for the first time, the Club of Rome discussed the problem of human development and published the report "The Limits to Growth". In 1972, the United Nations Conference on the Human Environment (WCED) held in Stockholm, Sweden, introduced the definition of sustainable development as "the development that meets the needs and aspirations of the present without compromising the ability of future generations to meet their own needs". In 1992, the first United Nations Conference on Environment and Development (UNCED) was held in Rio de Janeiro, Brazil, where the founding text of 27 principles of sustainable development was adopted as "The Rio Declaration on Environment and Development". These principles have the purpose to help countries to transit to another way of development and increase the well-being of the society as much as possible and sustainably. For example, new sustainable development indicators, such as the "Gross National Happiness" or the "Happy Planet Index", integrate social, economic and environmental criteria at the same level. The Rio Declaration in its principles 7, 8 and 16 obliges Governments to 1 :

- preserve, protect and restore the health and integrity of Earth's ecosystem;

- reduce and eliminate all the unsustainable production and consumption models;

- encourage the integration of environmental costs and the use of economic instruments, which consider that the polluter should pay for the pollution she/he has created.
The main aim of this article is the comparison of two governmental policies and their efficiency to stimulate the use of circular economy (CE) principles and achieve the goals of sustainable development including a high level of society's well-being.

\section{Materials and methods}

This paper considers several integrated efficiency criteria of CE model application. Firstly, a large empirical and theoretical review of the literature concerning $\mathrm{CE}$ in the context of sustainable development of the society was undertaken. Secondly, an analytical work about mechanisms and instruments of realization of the model of $\mathrm{CE}$ in France and Russia was performed. Finally, a comparison between the household waste management strategies in Paris and Moscow was carried out in order to undertake the statistical analysis in this study.

Following the need in a new model of economics and behaviour integrating sustainable ways of production and consumption, the $\mathrm{CE}$ model was taken under consideration. It began to take shape as early as in 1976 with the works of two scientists, W. Stahel and G. Reday. Their studies were devoted to the problems of life cycle analysis of goods and the waste recycling. The $\mathrm{CE}$ model is also based on the theory of "industrial ecology" developed as early as in 1990's by scientists of the National Academy of Engineering, USA. The principle of "cradle to cradle" invented by the $\mathrm{M}$. Braungart and W. McDonough in 2002 [2, 3] was also adopted by the CE-model 
Circular economy is applied with the intention to modify the currently acting linear model of economics (Figures 1 and 2). The Institute of Circular Economy, Paris, defines the CE as "a novel economic system based on the principle of ecosystems' functioning with the objective to avoid the dependence of economic growth on the exhausting natural resources thanks to the creation of innovative products, services, business models and innovative national policies". [4].

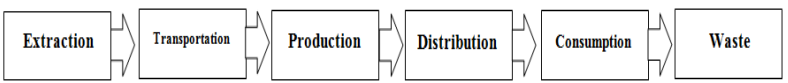

Fig. 1. The outline of the acting linear model of economics

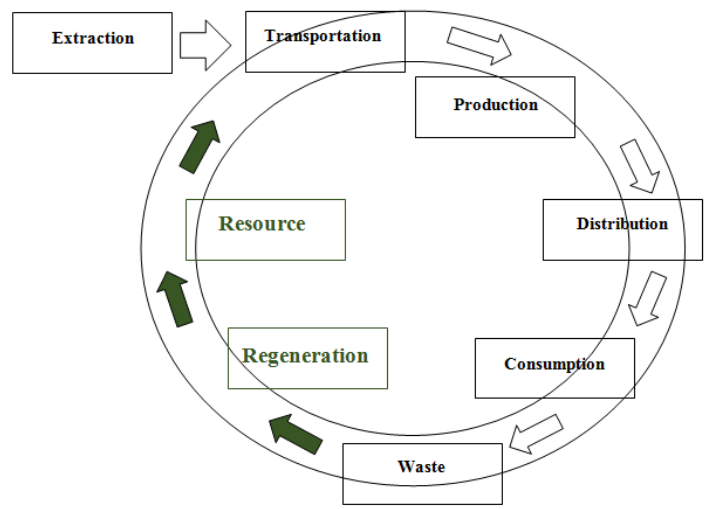

Fig. 2. The outline of the circular economy model

Formation of new closed loops in the recycling opens a prospective for an important reduction of the impact to the environment, stimulates the economy and results in an improved well-being of the society [5]. Indeed, the increased number of the recycling loops increases the amount of reused materials and saved energy, creates jobs, improves safety etc. In order to form a maximum number of the recycling loops targeting an accomplished transit to the CE model, it is important to use the waste hierarchy Four-R's Theory (reduce, recover, reuse, and recycle) inspired by the works of The Product-Life Institute (Fig. 3), at every level of production and consumption. Firstly, the society has to reduce the utilization of untapped resources, maximize the reuse and rehabilitation, finally recycling the products [5].

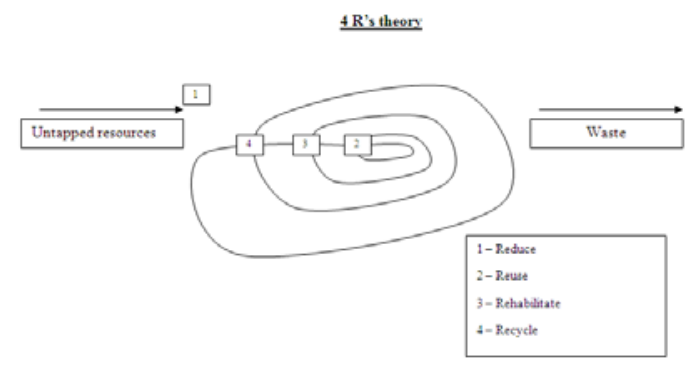

Fig. 3. The 4 R's theory

Implementation of this theory is possible by using four main well-known instruments [2-5]:

- Eco-conception;
At the beginning of the supply chain, when the product and its packaging are designed, the innovative products and production processes include "as little of nonrenewable resources as possible in favour of renewable resources, exploiting their turnover and associated with the waste recovery promoting reuse, repair and recycling" (French Environment and Energy management Agency).

- Industrial ecology or Industrial symbiosis;

Considering the analysis of material and energy flows, industrial ecology aims a global approach to the industrial systems. A number of companies in a given territory, in order to optimize production costs and reduce the risks, combines together in a wide trade network. The by-products and waste of a company may become a raw material for another one, which itself may in its turn become the supplier for a third company etc. In addition to raw materials, a common organization for the consumption of resources (energy, water, information etc.) and services (security, cleaning etc.) may be arranged.

- Functional economy;

This is the part of the CE accentuating the necessity to sell the use of a product rather than its property. The ultimate goal is to create the highest possible value for use as long as possible, while consuming as little as possible material resources and energy. The aim is to reach a better competitiveness and increase corporate earnings.

- Green economy;

The economy mainly focused on the social sphere of sustainable development and on the well-being of the society thanks to the rational and efficient use of natural resources. It is directly linked to the respect of nature, and seeks the maintenance of the natural capital balance (air, water, forests, etc.).

Despite global infatuation with $\mathrm{CE}$, only $6 \%$ of materials processed by the global economy are recycled contributing to closing the loop, indicating the global and the EU-27 economies being distant from the CE [6]. This makes the questions concerning the encouragement of companies and households applying the CE principles remain. The questions mainly concern the choice between the role of national governments and the use of market mechanisms in the $\mathrm{CE}$ principles implementation.

\section{Results and discussion}

To stimulate the CE strategy in France, the law entitled "Energy transition for the green growth" was enacted since August 17, 2015. Chapter IV requiring to "struggle with waste and promote the circular economy: from the design of the products to their recycling" continues and reinforces the previously acting laws on waste, setting more ambitious goals. The principles such as "the polluter pays", "proximity", "reducing the quantity and the hazard of waste", "extended producer responsibility (EPR)" and "local plans for household waste elimination" were adopted from the previous laws July 15, 1975, July 13, 1992, and from the laws of the 
Grenelle Environnement I and II (2009-2010). The new law obliges the companies and households of France [7]:

- to reduce the waste per capita production by $10 \%$,

- to properly treat $55 \%$ by 2020 and $60 \%$ by 2025 of the waste produced,

- to establish a special organization collecting, treating and recycling the biodegradable wastes, and

- to introduce a system of tax incentive.

In Russia, changes were introduced in the federal law "Production and consumption wastes" of January 1, 2015. In the law, wastes are defined and considered as a resource: the waste is characterized not as a "remnants of raw materials, semi-finished products or other products" but as "substances or objects". Thereby, it includes two more notions, "treatment" and "utilization" of waste, which give a chance to start using the model of CE in Russian economy. Once the definitions of waste changed, there is changed licensing strategy of business activity. At present, the license defines not only the placement and the elimination of waste, but also collection, transportation, treatment and utilization of waste [8].

One should note a substantial difference between the legislations of France and Russia. In France, due to the pressure of European laws to the national economy and the extended experience of world leaders Germany and the Netherlands in waste management, national legislation requires realization of ambitious goals and the responsibility of all economic actors. Indeed, in France an economical instrument called "extended producer responsibility (EPR)" is applied allowing the reduction and the treatment of various wastes at all stages of their life, from the moment of their production till their elimination. There are 18 different EPRs supported by laws, objectives and finances $[5,9]$.

In Russia, similar to France, the principle "the polluter pays" is applied in the waste management regulation. The current problem, however, is the limited encouragement of the waste recycling by law based on classical market stimulations. In the legislation of Russia, there is no incitation reducing the amount of waste, which is the first step in the realization of the CE model, which legitimately positions Russia at approximately the law of July 13, 1992, in France, although the economic and environmental conditions differing substantially.

In France, the household waste management is organized using the EPR principle. It came into effect with the adoption of the law in 1975 and is still in force being a virtuous constitutional provision forcing national manufacturers, distributors and foreign enterprises to contribute to their wastes' elimination. As a result, the problem of waste is managed by special organizations called "eco-organisms" having the duty of collection and treatment of wastes. The providers, i.e. producers of the waste have to participate in the funding of the wastes logistics, paying their environmental contributions to the eco-organisms every time new goods are placed to the market. The distributors or the suppliers of the wastes have to inform the consumers about their environmental contribution. Dependent on the character of wastes, the goods suppliers have also to participate in the collection and logistics of the waste. Commercial companies and households - the users of the goods, i.e. the future waste holders, have to sort the waste and ensure that the collection and sorting work will be accomplished at their own expense. Companies employed for collection and treatment of wastes provide full or partial management (collection, transport, preparation for subsequent use, valorisation and elimination) in compliance with the rules adopted for each type of waste. Local governments are involved in collection and/or sorting of certain types of household refusals within regulations and technical manuals issued for eco-organisms activities. The state and local authorities define the regulatory framework, including goals, allocation of responsibilities between the actors, decrees, etc.. They survey and control ecoorganism's activities and apply sanctions for violation of established rules (Figure 4) [5, 9].

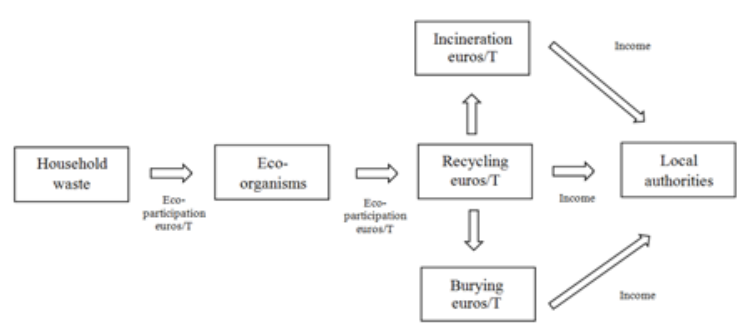

Fig. 4. Mechanisms of French legislation in household waste management (EPR tool)

In Russia, households and companies, i.e. the waste providers have the obligation to take care of the waste. For that, they employ companies providing full or partial management (collection, transport, preparation for subsequent use, valorisation and elimination). Local authorities have obligations to make landfills available for these waste management companies, providing appropriate sanitary norms, dependent on the waste hazard class. The companies pay for the placement of the waste in the landfills. The profit from the waste management activity is distributed among budgets with no specified purpose: 20,40 and $40 \%$ to the federal, regional and municipal budget, respectively. Authorities have to survey and control companies' activities applying sanctions against violation of established rules (Fig. 5).

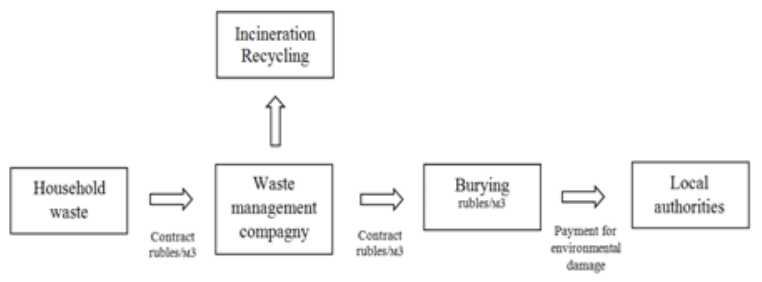

Fig. 5. Mechanisms of Russian legislation in household waste management

Here the two biggest regions of France and Russia, Ile-de-France with Paris and Moscow, are compared in the household waste management: (Table 1). 
Table 1. Key numbers in waste management in the city of Moscow, 2014, and in Ile-de-France, 2013* [9, 10]

\begin{tabular}{|c|c|c|}
\hline Parameter & City of Moscow & Ile-de-France \\
\hline $\begin{array}{c}\text { Population, } \\
\text { millions of } \\
\text { inhabitants }\end{array}$ & 11.92 & 12.01 \\
\hline $\begin{array}{c}\text { Occupied area, } \\
\mathrm{km}^{2}\end{array}$ & 2,511 & 12,012 \\
\hline $\begin{array}{c}\text { Amount of waste } \\
\text { collected, million } \\
\text { tonnes }\end{array}$ & $\begin{array}{c}3,4 \text { (solid } \\
\text { household waste } \\
\text { and oversize } \\
\text { waste of } \\
\text { residential sector) }\end{array}$ & $\begin{array}{c}5,516 \\
\text { (household } \\
\text { waste, } \\
\text { biodegradable } \\
\text { waste, solid } \\
\text { household } \\
\text { waste, other } \\
\text { types of waste) }\end{array}$ \\
\hline $\begin{array}{c}\text { Waste utilization } \\
\text { categories, tonnes }\end{array}$ & $\begin{array}{c}721,900 \\
\text { recycled } \\
\text { incinerated } \\
451,600 \text { landfilled } \\
370,000 \text { reused }\end{array}$ & $\begin{array}{c}3,419,700 \\
\text { incinerated } \\
701,200 \\
\text { landfilled } \\
384,300 \\
\text { recycled }\end{array}$ \\
\hline
\end{tabular}

* Both reports edited in 2015

The key numbers in waste management of the compared regions exhibit a substantial difference in the quantity of treated waste. Despite of the territory of Ilede-France 4.8 times exceeding the one of the city of Moscow, making more difficult the waste collection, the French region treats $62 \%$ more of waste.

In Moscow, $0.2 \%$ of the household waste have been recycled, $10.8 \%$ reused, $10 \%$ incinerated and $13.5 \%$ landfilled. According to the Department of Natural Resources and Environmental Protection of the city of Moscow, in 2014 about $35 \%$ of the household waste was treated. The priorities of the municipal government in waste management include the increase in the number of the waste reception gates, the introduction of statistical analysis on the consolidated inventory of waste production and consumption and the development of recycling and waste management systems.

In Ile-de-France, $13 \%$ of the household waste has been recycled, $62 \%$ incinerated, $12.7 \%$ landfilled and $7 \%$ of biodegradable waste recycled. According to the Regional Survey of Ile-de-France, in 2013 about $95 \%$ of the household waste was treated. The priorities of the regional government include the increase in recycling of household waste up to $45 \%$ by 2015 (in 2013 - only $27 \%$ ), the increased prevention and reuse of waste through the partnerships with organizations from the social and the solidarity economies, and the increase in sorting and recycling of biodegradable wastes.

\section{Conclusion}

There are two approaches to the model of circular economy implementation, "bottom-up" and "top-down". i.e. the companies initiating adoption of the model, and the government acts planting the strategy. In the process of implementing a circular economy strategy, it has been shown that the authorities play a leading role.

In France, the government creates and supports various tools to ensure all participants of the supply chain aspiring to the waste reduction, maximizing the treatment, reuse and recycling in order to achieve the goals of sustainable development and provide new ways to the higher well-being standards for the society.

In Russia, the Government interferes less and gives more power to the laws of free market. The waste acquires less value and is thus less reused, rehabilitated or recycled. This situation makes the sustainable development goals more difficult to achieve.

One should notice, that in France about $62 \%$ of the household waste is incinerated, increasing the dependence of France on this source of energy thus decreasing the possibility for the waste reuse and rehabilitation, making the strategy of circular economy less effective [6].

\section{References}

1. Report of the United Nations Conference on the Human Environment (Stockholm, United Nations publication, 1972)

2. S.Erkman, Vers une écologie industrielle. Comment mettre en pratique le développement durable dans une société hyper-industrielle (France, Paris, editions Charles Léopold Mayer, 2004)

3. C. Adoue, R. Beulque, L. Carré, J. Couteau, Quelles stratégies d'entreprise pour une économie circulaire moteur de croissance? Amorcer la transition, construire le modèle de demain (Institut de l'économie circulaire, 2014)

4. P. Ghisellinia, C. Cialanib, S. Ulgiatic, J Clean Prod, 114, 11-32 (2016)

5. W. Haas, F. Krausmann, D. Wiedenhofer, M. Heinz, J. Ind. Ecol., 19, 765-777 (2015)

6. PROJET DE LOI relatif à la transition énergétique pour la croissance verte, TITRE IV LUTTER CONTRE LES GASPILLAGES ET PROMOUVOIR L'ECONOMIE CIRCULAIRE : DE LA CONCEPTION DES PRODUITS A LEUR RECYCLAGE. Ministère de l'écologie, du développement durable et de l'énergie (NOR : DEVX1413992L/Bleue-1, 2014)

7. ConsultantPlus, federal law of Russian Federation from 24.06.1998 №89 "On production and consumption waste” (2015).

8. Agence de l'Environnement et de la Maîtrise de l'Energie. Les filières à responsabilité élargie des producteurs (REP) (ADEME.fr, 2016).

9. ORDIF, Cité Régionale de l'Environnement. Rapport sur la gestion des déchets ménagers et assimilés 2013. (2015).

10. A.O. Kulbachevsky, Doklad "O sostoianii okruzhaiuchie sredy v gorode Moskve v 2014 godu" (M.: DPiOOC; NIA-Priroda, 2015) 